\title{
The Development of Elementary School Headmaster's Managerial Performance- Assessment Model Based On Competence Standard
}

\author{
Wahyu Sri Ambar Arum \\ Faculty of Education,State University of Jakarta \\ Jakarta, Indonesia \\ Corresponding e-mail: wahyusriambararum@gmil.com
}

\begin{abstract}
This research is aimed to 1) formulate the model of headmaster managerial performance assessment based on managerial competency standard and 2) develop more effective model of headmaster managerial performance assessment. This research uses Research and Development method $(R$ and $D)$ and fishbone diagram (Fish Bone Diagram). This research was conducted in elementary school in East Jakarta area. The target of this research is the headmaster of elementary school and the Supervisor.This research are carried out through these following steps: Step 1 begins with preliminary observation to obtain the information that serves as the background of focus-selection and research's sub focus, identifying and determining schools. The data is obtained by the Tribe of Sub-district's Elementary Educational. Step 2 conducts interviews with school's supervisors, with experts and data retrieval related to the assessment of the current school-headmaster's performance, from the schools determined to represent the Elementary School of East Jakarta area. Step 3 performs the analysis of data and hypothesis. Step 4 arranges the assessment's model design of headmaster's performance based on the hypothesis and compile model guides before conducting trials, Step 5 performs the expansion and validation test. Step 6 revise the model, Step 7 Trials of model's practical and effectiveness. Step 8 refines the headmaster's performance assessment's model based on the results of the trial. Step 9 undertakes the development of an alternative model, based on the revised model. This is an alternative to improve the implementation of the model that has not been expected. The result of this study is the formulation of an effective headmaster's managerial performance assessment model for elementary school, the appropriate rating-model used is rating scale, checklist, behaviorally Anchored Rating Scale and management approach by objective. (1) Instrument contains all aspects of principal managerial performance (2). Every sentence on the instrument can be read easily and understandably. (3). The filling is easy and takes a short time. (4). There is innovative value in charging compared to previous Instrument with the online system, previously it is not online (5). The filling instructions are easy to understand. (6). Save paper because it directly uses computer or HP based on android (7) it is easy for data collection, simply by pressing the SUBMIT button
\end{abstract}

Keywords: model of assessment, headmaster managerial performance's.

\section{INTRODUCTION}

\section{A. Background}

The changing world of education towards the better is a necessity that is done to achieve meaningful education, therefore we should prepare the educational model in accordance with the demands of today's world. The right model will certainly produce quality learners in accordance with educational goals. One of the goals of education is to prepare individuals to meet their individual needs to be able to adapt or adapt to the environment. In order to achieve the educational objectives, it is necessary to educate the competent in managing education. Headmaster is a very important role in the world of education.

Head of the school is required to have managerial skills in addition to personal skills, social, supervision, entrepreneurship. In general, the weakness of the Headmaster is in two competencies, namely supervision and managerial competence. The test results from 400 Headmasters conducted by the Directorate showed the same results. Headmaster managerial competence will have an impact on activities within the organization. This is in line with the opinion of Usman that the success of the Headmaster in achieving his goals is predominantly determined by the reliability of the school's management, and the reliability of school management is strongly influenced by his school Headmaster's better leadership capacity

A professional school Headmaster can better manage his or her school. The importance of the Headmaster's leadership was put forward by Ruth Love who stated :

"I have never seen a good school and without a good Headmaster dan James B.Conant, ',The difference between a good and poor.

Hoy and Miskel, Argues that leaders and leadership are important because they serve as anchors, providing better guidance and modeling models for better Headmaster's performance and change, and are responsible for the effectiveness of the school.

The ability of the Headmaster's performance requires long-term knowledge and experience, eg in the areas of planning, organizing, and supervision. Yet to this day it seems that not all Headmasters have good managerial performance. Where is the error whether the measuring instrument used to assess the performance of the Headmaster is still not appropriate / optimal assessment system. Effective Headmaster performance is an indicator of school success in achieving its objectives. 
Generally to achieve school success has to do with planning and implementation related to empowerment of human resources, financing, and ability to develop school. In relation to the budget, according to the concept of School-Based Management, for operational costs already supported by the government through BOS, it is difficult for schools to collect fees from parents. The thing to note is the willingness of Headmasters and human resources in schools to flourish, although the source of funds and fund management is limited. Assessment of Headmaster performance is one of the coaching strategies to maintain professionalism in carrying out its duties, career coaching, improvement of competence and quality assurance. Assessment of Headmasters' performance can be done by eliminating the problems that have hampered the progress of the school. There are various factors that have not been optimized the performance of the school Headmaster indicated due to limited ability and skill, unstable personality, low work motivation, low salary or reward, environmental factors that are less conducive, lack of rewards, limited facilities and infrastructure, and limited funds In developing the school.However, during this assessment of Headmasters' performance is more on viewing documents from the administration field, so this less motivate the Headmaster to better achievement that impact on its performance, while the performance of the Headmaster has a strategic role therefore researchers interested in raising the problem Performance of headmaster.serta develop model of headmaster performance assessment and find model of performance of headmaster's effectiveness. By considering result of deep analysis to headmaster's performance hence determined priority area which become focus. The main assessment of performance in this study is the Headmaster task of the Headmaster in the managerial field.

\section{B. Formulation of the problem}

Based on the background of the problem, then the formulation of the problem in this study are:

1.How is the process of developing a model of managerial performance of the Headmaster?

2.How is the result of developing the Primary School Headmaster Assessment model? .

\section{Research Purposes}

1. Knowing the model of assessment of the current managerial performance

2..Develop a Headmaster Managerial Performance Assessment Model through trial / validity testing

3.The preparation of scientific reports and articles.

\section{Output / Product}

1. Model Assessment of the performance of the Headmaster is effective.
2.Finalize the development of the Headmaster's performance assessment model.

3. Building Guidelines for the performance of Headmasters.

4.The compilation of research reports and scientific articles.

\section{E. The Benefits of Research Results}

The results of this study are expected to be useful as follows:

1. Theoretically

Theoretically, the results of this study are expected to contribute significantly in the development of scientific repertoire, especially the model of performance assessment of the Headmaster that has been running.

\section{Practically}

Practically, the results of this study are expected to be useful for:

a. Headmaster

Through the development of the Headmaster managerial performance assessment model, it is expected that the Headmaster can know the shortcomings and the advantages of school managerial performance so that it can be used as material to improve the school quality.

b. School supervisor

The results of this study are expected to be used as a reference and reflection in assessing the performance of Headmasters, in addition supervisors can foster schools by using performance assessment models accurately, correctly and more precisely.

\section{c. Tribe of Basic Education Office}

The results of this study are expected to be used as a tool or policy-making materials in an effort to improve the quality of primary school through a better model of performance of the Headmaster of primary school.

d. Ministry of Education and Culture

The results of this study are expected to be used as a tool / ingredients of policy making or advocacy nationally in an effort to improve the quality of education through coaching Headmasters.

\section{LITERATURE REVIEW.}

\section{A. Understanding Development}

Development means a gradual process of change in a direction that tends to be higher and widespread and deeper to create a perfection. Development in education is an educational effort both formal and non-formal that is carried out consciously, planned, directed, organized and responsible in order to introduce, Grow, guide, and develop a basic personality of knowledge and skills of talent, desire and ability, as a provision for the next on its own initiative to add, and develop itself. 


\section{B. Definition of the Model}

According to the Indonesian Dictionary the Model is a pattern (eg, reference, variety) of something to be created or produced.

While Sudji believes that

The model is an abstraction of the actual system, in a simpler picture and has an overall percentage level, or the model is anabstraction of reality by simply focusing on some traits of real life.

The types of models can be divided into five different classes:

1. Class I division according to its function, among others:

a. Descriptive Model, ie a model that only describes the situation of a system without recommendations and forecasting;

b. Predictive models, ie models that show what will happen when something happens;

c.. Normative model, ie the model that provides the best answer to one problem. This model recommends actions to be taken;

2. Class II, division by structure

a. The iconic model is a model that mimics the original system but on a certain scale.

b. Analog models, ie models that mimic the original system by simply taking some of the main characteristics and describing it with other objects or systems analogously.

c. A symbolic model, a model that describes a system that is viewed with symbols, usually with mathematical symbols.

3. Class III Distribution according to time reference is a) static, ie a model which does not include the time factor and formulation; And b) dynamic, ie the model that has time for its formulation.

4. Class IV, the division according to the reference of certainty that is:

Deterministic, Probabilistic, Game.

5. Class $\mathrm{V}$, the division according to the level of generalities are: general, specialKelas III Pembagian menurut referensi waktu yaitu a) statis, yaitu model yang tidak memasukkan faktor waktu daan perumusannya; dan b) dinamis, yakni model yang mempunyai waktu untuk perumusannya.

6. Class IV, the division according to the reference of certainty that is:

Deterministic, Probabilistic, Game.

7. Class V, the division according to the level of generalities are: general, special

The model to be compiled in this study is more on the normative model, ie the model that provides the best answer to one problem and this model gives recommendations actions that need to be taken.

\section{Research and Development ( $R$ and $D)$.}

The research used to produce a particular product and test the effectiveness of the product tsb. it is reinforced by Sukmadinata, which states that Research and development is a new product / refinement of existing products, which can be justified.

\section{The nature of performance}

According to Purwodingingrat, the definition of Performance is something that is achieved, the achievement shown or the ability to work.

Michel Armstrong defines Performance as follows

Performance is often defined simply in output terms-the achievement of quantified W.J.S Poerwodarminto in the Indonesian general dictionary objectives. But performance is a matter not only of what people achieve but how they achieve it. High performance results from appropriate behavior, especially discretionary behavior, and the effective use of the required knowledge, skills and competencies.

Based on this definition, performance is defined simply as a result of a measurable goal achievement. But performance is not only what is achieved by people but how they achieve it. High performance results from appropriate behavior, especially behavioral wisdom, and effective use of required knowledge, skills and competencies.Regarding performance, Richard L. Hughes, Robert C. Ginnett, and Gordon J. Curphy argue, Based on the definition of such performance only "performance on the other hand, concerns those behavior directed toward the organization's mission or goals or the products and services resulting from those behavior". Performance on the other hand, focuses on behavior that leads directly to the mission or objectives of the organization or the products and services resulting from that behavior. Thus it can be concluded that the performance is the result obtained by an organization, as well as individuals to achieve organizational goals both profitable oriented and nonprofit oriented generated during a certain period. Performance in performing its function does not stand alone, according to Sabine Sonentaga is as follows:

A supportive context for facilitating performance is one where goals are clearly defined, work methods are made known, rewards are established that motivate effort, equipment, materials, supplies, etc., are made available so that work is accomplished efficiently, and management is supportive and fair.

A supportive context to facilitate performance is a clear objective, work methods created to be known, awards are set so as to motivate efforts, equipment, materials, materials, etc., made available so that the work can be achieved efficiently, and supportive and fair management. Thus it can be concluded that the conceptual definition of performance is the Headmaster's behavioral value that contributes positively to the fulfillment of organizational goals, while the operational definition is the score of the Headmaster's assessment of the implementation of the task and responsibility. In improving Burhanuddin's performance in administrative 
management and education leadership analysis books suggests that efforts to improve performance are:

1.Pay attention and meet personal and organizational demands

2. Job information and duties of each member of the organization

3. Effective monitoring and supervision of school organization members

4. Assessment of school staff program in the framework of improvement and development as well as optimal development.

5.Implement transactional and democratic leadership.

Dirawat Busro Lamberi and Sukarto Indrafachrudi share factors that affect performance in two categories namely: Internal and external factors. Internal factors are factors that come from within a person that can affect a person's performance in the work while the external factors are factors that can affect its performance. Performance will succeed if there is motivation that will move to work more excited. With earnest faith and effort and strong motivation, the Headmaster will do his job well and succeed in improving his performance. Managerial performance is the achievement of measurable goals in the managerial field.

\section{E. The Nature and Purpose of Performance Assessment \\ 1. Understanding Performance Assessment}

Assessment is the process of collecting, processing, analyzing and interpreting the data as a decision-making material. Assessment of any activity interpreting the ASSESSMENT data of activities to obtain information. In this regard, each assessment activity leads to decision making. A common assessment used to assess individual or group performance is a statement based on a number of facts to explain the person's / something's characteristics.

Performance assessment is an assessment of each key task activity item in work, including Headmaster in order to foster career of rank and position. The Headmaster in accordance with the permendiknas is the teacher who has additional duties as Headmaster / madrasah.

Performance assessment is a formal process to conduct periodic review and evaluation of work. The teacher performance assessment with additional task as Headmaster, hereinafter referred to as Headmaster performance assessment is the process of collecting, processing, analyzing, and interpreting real data. Its effectiveness is determined by measuring the success of reaching the target On each indicator compared to the targets set in the program.

\section{Assessment Goals}

Mulia Nasution in Personnel Management stated that the Performance Assessment Goals are as follows: a. Have or give influence as a motivator

b.Stimulating the improvement and development of a sense of responsibility

c.Increase productivity if they know the purpose and objectives of the assessment.

d.Increase understanding between superiors and subordinates

e.For a raise and give promotion

f.Enicipate the need for employee training and development

g.Avoid the choice of Headmaster's love of the teacher

h.Planning human resources

i. Measuring one's leadership success.

The purpose of performance evaluation according to Marihot Tua Efendi's general purpose is to provide feedback to employees in an effort to improve the appearance of their work and efforts to improve organizational productivity and specifically related to employee policies for promotion of salary increases and training. Performance assessment also aims to understand the performance of a person who requires a process of interrelated activities. The activity consists of identification, observation, assessment and development of the work of employees in an organization. Identification stage is the first stage of the process consisting of the determination of the elements to be observed. Next stage of observation is the stage of observation carefully and periodically. All assessed elements are carefully observed in order to make reasonable and precise judgments, resulting in accurate assessment results.

The performance assessment limits, in the opinion of Trespeces cited by Hari Setiadi, are various tasks and situations where test takers are asked to demonstrate deep understanding and application of knowledge, as well as skills in various contexts..

\section{F. Duties and Functions of the Headmaster in Implementing Managerial Competence 1. The Headmaster's Duty}

The Regulation of the Minister of National Education Number 28 Year 2010 explains that the Headmaster's tasks include: (1) school / madrasah development effort undertaken during the position of Headmaster / madrasah; (2) improvement of school / madrasah quality based on eight national education standards (SNP) under the leadership; (3) professionalism development effort as Headmaster / madrasah.

\section{Function Headmaster}

According to Stoner as quoted by Wahjosumijo, states there are eight functions Headmaster Headmasters include:

a). Headmasters work with and through other people (work with and through other people) 
b). School heads are responsible and accountable (Responsible and accountable)

c). School heads must be able to deal with various issues (managers balance competing goals and set priorities)

d). The head of the school must think analytically and konseptionally

e). The head of the school as the interpreter

f). Head of school as a politician

g). Head of school as a diplomat

h).The headmaster serves as a difficult decision maker

Thus the task and function of the Headmaster refers to the competence to be achieved so as to affect its performance.

\section{Headmaster Managerial Competency Standards}

In accordance with the Minister of National Education of the Republic of Indonesia no.13.tahun 2007 on Standards Headmasters / Madrasah. standard Headmaster Managerial Competence include:

Formulate school / madrasah planning for various levels of planning.

Developing school / madrasah organizations as needed.

Lead the school / madrasah in order to optimize the utilization of school / madrasah resources optimally.

Lead the school / madrasah in order to optimize the utilization of school / madrasah resources optimally.

Managing change and development of schools / madrasah towards effective learner organizations.

Creating a conducive and innovative school and school culture and madrasah for the learning of learners.

Manage teachers and staff in order to optimally utilize human resources.

Manage facilities and infrastructure in the framework of optimal utilization of human resources.

i). Managing school / madrasah and community relationships in order to seek the support of ideas, learning resources, and school / madrasah funding.

j). Managing Learners in order to receive new learners, placement and capacity building of learners

k). Managing curriculum development and learning activities in accordance with the direction and objectives of national education.

1). Managing school / madrasah finance in accordance with accountable, transparent and efficient management principles.

$\mathrm{m})$. Managing the administration of schools / madrasah in support of achieving school / madrasah goals.

n). Managing school / madrasah special service units in supporting learning activities and activities of learners in schools / madrasah.

o). Managing school / madrasah information systems in support of programming and decision-making.

p). Utilizing advances in information technology for improved learning and school / madrasah management.

q). Monitoring, evaluating and reporting the implementation of school / madrasah program activities with appropriate procedures, and planning for follow-up.

\section{G. Scope of Headmaster Assessment Performance}

Minister of National Education Regulation No. 35/2010 explains that teacher performance assessment that has additional task as Headmaster / madrasah includes six components of assessment, Minister of National Education Regulation No. 19 of 2007 on Education Management Standards explained that the management of educational unit includes program planning, implementation of work plan, supervision and evaluation, school / madrasah leadership, and Management Information System.

School / madrasah educational unit is led by a headmaster who is able to lead with indicators have knowledge, skills, and behaviors that are owned, lived, mastered and realized in carrying out professional duties in accordance with education management unit standards,namely personality and social, leadership, school / madrasah development, resource management, entrepreneurship, and supervision of learning.

In the overall regulation, the Headmaster / madrasah must demonstrate the ability:

Preparing school / madrasah planning for various levels of planning.

Lead school / madrasah in order to optimize the utilization of school / madrasah resources optimally.

Managing change and development of school / madrasah toward effective learner organizations.

Creating a conducive and innovative school and school culture and madrasah for the learning of learners.

Managing teachers and staff in the context of resource utilization

Managing learners in order to receive new learners, placement and capacity building of learners.

7. Managing curriculum development and learning activities in accordance with the direction and objectives of national education.

8. Managing school / madrasah resources in accordance with effective, efficient and accountable management principles.

9. Utilizing advances in information technology for improved learning and school / madrasah management.

10. Plan an academic supervision program in order to improve the professionalism of teachers.

11. Implement academic supervision of teachers by using appropriate supervisory approaches and techniques.

\section{H. Inhibition in performance assessment}

In the performance assessment sometimes there are some obstacles. Challenges in performance assessment are misappraisers, lack of appraisers, ineffectiveness of practices and organization policies and poor assessment forms. In the performance assessment sometimes interrupts or intermediaries behave subjective. It is proposed by Sondang P.Siagian that "Supervisors in 
conducting judgments act subjectively due to hello factors of extreme effects are soft and generous as well as being harsh and stingy. To overcome barriers in performance assessment, Sjafri Mangkuprawira said that the implementation of assessment activities should be

1. Free from Hallo Securities

2. Create a calm and calm atmosphere

3. Discuss the work personally

4. The scoring form used should be good

5. Listener should be good supervisor

Thus if the performance assessment is declared eligible, there will be no perception of the various from the employees to the leadership of the organization. Performance implementation at every level of the organizational structure should provide clear limits on the elements that will be judged both for managers and employees Operational organizational structures should provide clear constraints on the elements that will be assessed for both operational managers and employees for organizational objectives to provide clear restrictions on elements that will be assessed for both operational managers and employees.

\section{Method Performance Assessment}

Performance assessment is done with the effort to achieve the expected work. According to Marihot Tua Efendi Hariandja that "the assessment method is grouped into two categories: past-oriented assessment and futureoriented assessment.

The past-oriented assessment method is the assessment of work behaviors done in the past before the assessment is done. This method consists of Rating scale, Checklist, lithical intentional technique, behavioral evaluation scale, observation, test, and comparison method. While future-oriented assessment methods are an assessment of the employee's potential for future employment, this method of assessment consists of 1. Self-assessment, 2.Management by objective, 3.Paluologis psychologically, 4.Assessment center.Performance assessment can be done in various ways or methods.

Mondy dan Noe yang dikutip oleh Mutiara S.Panggabean Suggests employee performance assessment methods are as follows:

Rating scale

By using this method the results of the performance assessment of employees recorded in a scale. Scale was divided into seven or five categories and arena concepts that will be judged qualitative, then the categories used are qualitative, ie from very satisfactory to very unsatisfactory. Is used because it is very simple and can be used to assess more people in a relatively short time.

2. Critical Insidents (Insiden-insiden kritis)

With this method the assessor performs a critical moment-only assessment, that is where the behavior / employee can make its part very successful or even vice versa. Essentially this assessment method can not stand alone but must be combined with other methods.
Essay

Using this method the assessor writes short stories describing employee performance. This method tends to describe work performance rather than daily performance. This assessment relies heavily on the ability to write an appraiser. Once the performance is reviewed, a positive evaluation can be negative if the assessor can not write it good.

Work Standards (Standards of Work)

This method compares the performance of employees with predefined standards. Standards reflect the normal results of the average worker in a normal business.

\section{Ranking}

With this method the assessor simply puts all the employees rated into the rank order. The scores compare the one employee to the other to determine who is better and who then puts the employee in the best order to the worst.

Forced Distribution (Distribution imposed)

In this method it is assumed that employees can be grouped into five categories: the best category (10\%), good category $(20 \%)$, coverage $(40 \%)$, bad $(20 \%)$, very bad $(10 \%)$.

Corced-choice and Weighted checlist performance report (This selection requires assessors to choose which employees can represent the group. The assessed factors are employee behavior and the assessor gives a positive or negative value, but The assessor does not care about the weight of his judgment.

.Behaviorally Anchored Scales

It is a valuation method based on an assessment note that describes employee behavior that is very good or bad in relation to the implementation of work.

Approach Method of Management By Objective (MB0).

This approach, each employee and supervisor, together determines the organization's goals, individual goals and suggestions for improving organizational productivity. Based on that opinion, it can be analyzed in principle. Rating scale is compiled from the list of characteristics, in the condition that there are columns containing very good categories, good, enough, less, very less. While the judgment aspect applies honesty, engagement, perseverance, cooperation, discipline, tidiness. Critical incidents are carried out with notes of all occasions regarding employee behavior, and the last of these assessments for the tutor.Essay method is commonly used to assess knowledge, skills or performance. General checklist of questions, and questions weighted to calculate employee performance assessments.Force Choice of method using a five-scale.

\section{J. Relevant Research Results}

With the title of the research that the author lifted the relevant research with the research is as follows: 1 . Research conducted by Udin Sayefudin Saud, Ahmadi 
about the development of Headmasters of Headmasters (study on the effect of training and competence on the performance of elementary school Headmasters in Natuna district island province Riau, which aims to determine the factors that affect the performance of the Headmaster concluded the competence of elementary school Headmasters in Natuna district Riau Islands Province positively affect the performance of primary school Headmasters in Natuna district Riau Islands Province.

2. In a study conducted by Teguh Triwiyanto on Monitoring and evaluation implementation and reporting for performance assessment of Headmasters, found that if evaluations were conducted to assess Headmaster managerial performance then clear tools were needed.

3. Research conducted by Dedeh Saadah (2013) on Headmaster performance theory (correlation study between organizational climate and interpersonal communication with Headmaster performance of elementary school in Karawang) concluded that there is positive and significant relationship between organizational climate and school Headmaster performance. Conducive to the performance of the Headmaster will also increase2. There is a positive relationship between interpersonal communication with the performance of the Headmaster. If interpersonal communication more effective, then the performance of the Headmaster will increase.3.Terdapat positive relationship between organizational climate and interpersonal communication together with Performance of the Headmaster.

Thus it can be concluded that the organizational climate and interpersonal communication is closely related to the performance of the Headmaster.

Two field studies and laboratory study examined the influence of reward for high performance pressure,intrinsic interest .Study found ;1.Employees expected reward for High performance pressue,was positively related to performance pressure which,us turn,was positively,associated with employees interest in their job.2. replicated this finding and showed that intrinsic interest,produced by performance pressure, was positively related to supervisor's reating of creative performance,3.Found that college students receipt of reward for high performance increased their experienced performance pressure which in turn,was positively related to intrinsic interest and creativity.

\section{THE RESEARCH METHOD}

\section{A.The method and research phases}

This research uses Research and Development (R and D) method by Bolt and Gall and also uses the Fish Bone diagram. According to Bolt and Gall that is quoted by Sugiyono (2009), Research and Development method is a research method that is used for producing certain products and to examine products' efficiency. The steps of this research consist of 1 . The information of the data, 2.The model design, 3.Product's development, 4.Trialing the Model, 5.Revising the Model, 6.Trialing the Model, 7. Analyzing the operational model, 8. Revising the model, 9.Finalizing the model.

The developed model in this research is done by some phases, there are: On the first year, the first phase is identifying and deciding a school that wants to be examined. The data is collected from Primary School Department in the Sub-district, and then study the literature. The second phase is interviewing the school superintendent and collecting the data related to the headmaster performance assessment that has done from the selected school, representing primary school in Jakarta region. The third phase is analyzed data and hypothesis then collected and made the temporal conclusion as the source to construct the model design. The concluded truth is not based on number of individuals' consideration, but it emphasizes more on important features of various applied the category and then connecting to each other to make an image of better model of headmaster performance assessment, based on conclusion that is collected from the second phase. The fourth phase is arranging the model plan of the headmaster performance assessment and making the guidance to make the model itself. The fifth phase is to trial or validity test. The sixth phase is revising the model which is done based on the result of trial or validity test. The sevent phase is developing alternative models of the headmaster performance assessment. On the second year, the first phase is revising. The second phase is examining the effectiveness and efficiency the developed model based on the revision result. This is an alternative way to revise the implementation which is not suitable from the wished for. The third phase is analyzing data and conclusion based on the result of the research which is the finalization of the headmaster performance assessment developing model viewed from managerial competence aspect.

This research uses qualitative approach. The aim of this approach is to show an image of an object that has been examined in complete, systematic, factual, accurate, natural and comprehensive way in headmaster performance. The data is collected descriptively by the technique of observation, interview, and documents study. In this research, the headmaster will be the source of data as the key informant and school superintendent in the part of Primary School Department in East Jakarta Sub-district.

\section{B.The Research Target}

This research is taken in Elementary School at East Jakarta Sub-district region. The target of this research is the headmaster of Elementary School in East Jakarta are 30 Elementary schools, and 10 School Superintendents .This research is taken continually, starting from the first observation to collect information that will become the background of focus and sub-focus choosing of the research. This region is selected to be the place of this 
research because this region is strategic and many elementary schools there are the National Standard Schools ( ex The stub of International Level School).

\section{C.The Data and The Sources}

The source data of this research divides into primary source and secondary source. The primary source consists of the main data derived directly from the interviewee that is school superintendent through interview and participative observed data from researcher in the field. The secondary source comes from supportive documents which are collected directly from documentations that have relationship between the object and the focus of the research. The collected data from the field will be processed and reduced to be meaningful information.

\section{D.Collecting and Recording Data Procedure}

The collected data in this research is taken in natural setting with the following steps:

Observation

An observation is done with participative observation approach. This approach makes the researcher collecting the information easily. Thus, there will possibly be new inventions in a positive way or even an obstacle in developing model.

\section{Interview}

The interview is done by using structured interview where the researcher makes an interview guide. This guide consists of some questions that are arranged based on instrument clues. The interview in this research will use aid such as tape recorder, note book, and camera.

Documentation

Documentation study is done by collecting documents that have relationship with the headmaster performance. This documentation studying is done in order to support the result of observation and interview, so that this research will have great credibility.This early research through observation, interview, and documentation study is done to compile the data and be consideration on the next research.

The model trial.

For the first time, all instruments it is done manually. Then, it is done in online for compiling data quickly.

\section{E Research Data Analysis}

The data analysis is done after collecting data continually, reducing data and presenting data. Reducing data means collecting, choosing and focusing on important data and disposing the not needed one so that the reduced data will show a clearer image. After reducing the data, the analyzed data is presented in narration form with group of data that has been made in reducing phase. The result in brief narration form is then made into a temporal conclusion until there is another evidence to support this result.

\section{F. The Used Instrument in Developing Model Research}

Some instruments that are used in developing model managerial performance assessment of elementary school headmaster, are:

The headmaster's identity data form

The instrument of briefly filling content

A check list

An observation and interview guide

The questioner online

The achievement note during the process of assessment

The performance assessment test form that should be filled with

The conclusion and recommendation form that should be filled with

Thus, it can be concluded that the awarding has an effect on to the performance. Regulation of the Minister of National Education Number 13 Year 2007 about the Headmaster standard explains the five dimensions of the Headmaster's competence: personality, managerial, entrepreneurial, supervision, and social.

\section{The Phase I (the first year)}

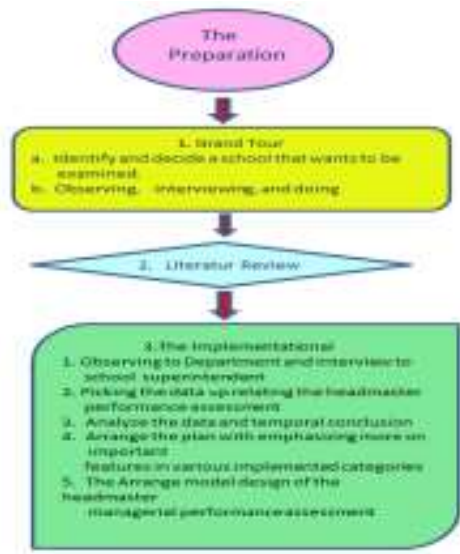

The Phase 2 (the second year)

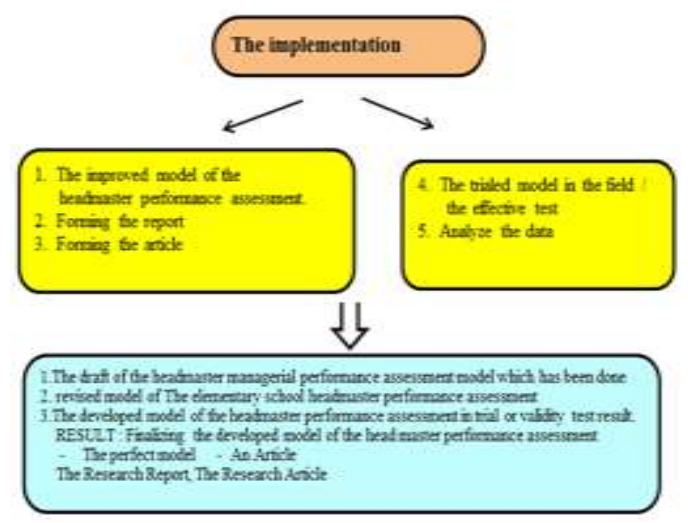

\section{G. Output / Product}

1. Model Assessment of the performance of the 
headmaster is effective

2. Finalize the development of the Headmaster's performance assessment model

3. Building Guidelines for the performance of Headmasters

4. The compilation of research reports and scientific articles

\section{H. The research plot with Fish Bone diagram}

To make it clear, this research plot can be seen through Fish Bone diagram which is also known as cause effect diagram as follow:

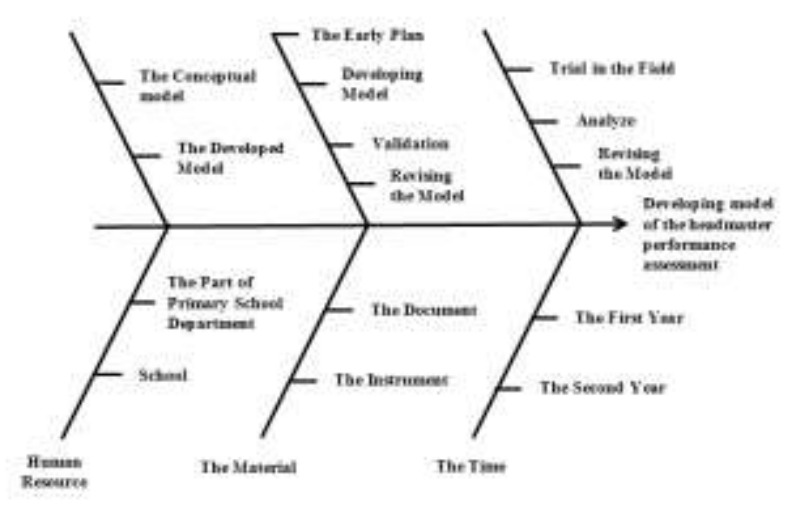

Figure 1: The Fish Bone diagram

Briefly, this research is done for two years while the human resources are from the part of Primary School Department in Sub-district. As the main source in this research, there are documents and instrument. The steps of this research consist of studying the model conceptually. Developing the model: 1.The early plan, 2.The planned model, 3.The developed model, 4. Validity test, 5.Revising the model, 6.Trialing / testing in the field, 7. Analyzing the operational model, 8. Revising the model, 9.Finalizing the model.

\section{The Used Aid and Equipment}

A laptop, A flash disk (an USB driver), A printer,An LCD,A tape recorder,

Paper and any other consumable material, A map, The $\mathrm{CD}$, and $\mathrm{A}$ wi-fi

\section{RESEARCH RESULT AND DISCUSSION}

Base on the theoretical study of Headmaster Managerial Performance Concepts and Problem identification, the next step is documentation research by interviewing the representatives of the headmasters and the supervisor. The data obtained to strengthen the drafting of the model. Previously the Headmaster Managerial Performance Assessment is done manually, however, due to the progress of technology then the primary evaluation instrument tested/validated, developed by online

The characteristic of innovation in assessment model lies in the system taken, namely from the online scheme, while compared to another assessment model, the instrument type of evaluation instruments are more varied.

A. Data Presentation

Aspects of Principal's Managerial Performance Assessmen. model refer to the principal competency standards. Aspects of headmaster's managerial performance assessed are:

1. The ability to set up different school planning for any levels.

2. The capability in promoting the school's institution based on the necessity.

3. The capacity to lead the teachers and the staffs in optimizing the human resources.

4. The ability to manage the teachers and the staffs in optimizing the human resources.

5. The ability to manage school's facilities and infrastructures in optimizing the utilization.

6. The ability to manage the relationship between the school and the community to gain supports of ideas, learning resources, and school finance.

7. The ability to manage the students, especially in the new student's enrollment, their placement, and their capacity building.

8 . The ability to manage the curriculum development and the activities of teaching and learning by the direction and objectives of national education.

9. The ability in managing school's finances with the principles of accountability, transparently and efficiently 10. The ability to manage the school's administration to support school's activities:

11. The capability in managing school's specific service units to support the student in learning and activities:

12. The ability in applying the entrepreneurship principles in creating innovation that is useful for school improvement.

13. The ability to create a working culture and favorable condition for a student in learning.

14. The ability to manage school information system in supporting the programming and the decision making:

15. Having skill in making good use of the advanced information technology for improving the learning and school management:

16. Having expertise in managing production/service activities in supporting the school financing sources and as a source of learning side:

17. The ability to carry out supervision on the implementation of school activities according to applicable supervisory standards. 


\section{B. The Used Instrument in Developing Model}

The instruments applied to develop the assessment model of the Managerial Performance of elementary school headmaster is the Headmaster's Identity Data. They are a brief filling content, a checklist, an observation and interview guide.

The online instrument about the Headmaster's Performance at a managerial level, the scopes also concern regarding knowledge, skills and performance factor. The instruments adapt to the needs of the schools, and to serve human resources in the schools and the communities and also to support the improvement of educational quality, the instrument enhanced by involving education experts. The contents of the instrument are intended to: 1) revise the tools by using easy-to-understand application programs, 2) improve instrument readability, 3) make easy in the calculation of scores, 4) facilitate the implementation and achievement of goals.

Table 1 below is the data of the test results through the online instrument

Tatet 1.

Fiesult of assessment of the Managerial Porformance Instruemnt by the Heodinastor

\begin{tabular}{|c|c|c|c|c|c|c|c|c|}
\hline \multirow[b]{2}{*}{ No } & \multirow[b]{2}{*}{ Foed Aquer: } & \multicolumn{2}{|c|}{ pous ammer } & \multirow{2}{*}{14} & \multirow[b]{2}{*}{ D } & \multirow{2}{*}{\multicolumn{2}{|c|}{ in Seres }} & \multirow{2}{*}{$\begin{array}{l}\text { wespos } \\
\text { wen }\end{array}$} \\
\hline & & is & 4 & & & & & \\
\hline 1 & 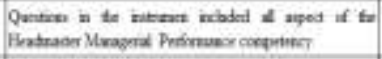 & 24 & 4 & 0 & 0 & 9 & 14 & 48 \\
\hline 2 & 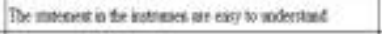 & 3 & $x$ & + & D & 0 & s & 13 \\
\hline 3 & 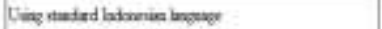 & $n$ & in & $n$ & (0) & " & 14 & 4.7 \\
\hline 4 & 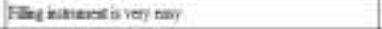 & $B$ & $T$ & 0 & 0 & a & 14 & 4 \\
\hline 3 & 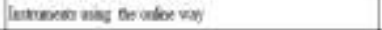 & 22 & . & 2 & e & a & we & 5.7 \\
\hline 5 & 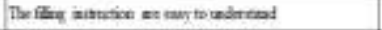 & 23 & 4 & 3 & 0 & 0 & 140 & \$7 \\
\hline 7 & 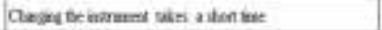 & $x$ & 3 & 3 & 6 & a & us & 15 \\
\hline \multicolumn{8}{|c|}{ bond } & $\mathrm{nz}$ \\
\hline \multicolumn{8}{|c|}{ Moost if Weiphen Meif. } & 45 \\
\hline & 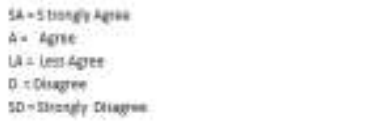 & & & & & & & \\
\hline
\end{tabular}

Table 1 presents test results data from 30 headmasters of National Standard Elementary School (SSN) in East Jakarta on the feasibility of Instrument of Headmaster Managerial Competence, and the results of the calculation are as follows:

1. There are 30 elementary school headmasters evaluated the instrument. There are six aspects evaluated, and the scale of the answer has a 10range from 1 to 5 with the weight of the value, i.e., "Strongly agree (5), agree (4), less agree (3), disagree (2), and strongly disagree (1) "

2 . The scoring using Weighting and weighted average. In the 1 st aspect namely "Questions in the instrument cover all aspects of the headmaster managerial performance competencies"; answered strongly agree as many as 24 people and the answer agreed 6 people, then the weighted score is $=(24 \times 5)+(6 \times 4)+(0 \times 3)+(0 \times 2)+$
$(0 \times 1)=144$, for weighted average obtained $=144: 30=$ 4.8. Most respondents agreed with the statement that the instrument is easy to understand. The results are $2 / 3$ of the number of respondents agreed. The weighted average $=3.2$. In the same way for the next aspect, the consecutive weighted average results are for the statement "Indonesian used refer to the EYD " $=4.7$ agree; "Instrument filling is very easy" $=4.8$; "Instrument using online" $=4.7$; "The instructions are easy to understand" $=4.7$; The instrument filling takes a short time $=4.7$

Most respondents agreed that the statement in the instrument is easy to comprehend. Most respondents stated strongly agree with the statement by using Bahasa Indonesia by EYD. How to fill Instrument is very easy, especially by using the online. The filling of the instrument takes a short time, it is stated strongly agree $2 / 3$ of the number of respondents, and easy to understand, there are $76 \%$ of respondents strongly accept the statement. However, only a small portion of the respondent declarations in the instrument is easy to understand. Most respondents simply agree that the statements contained in the instrument are easy to comprehend.

Based on the calculations from all aspects, it can be known that generally, the respondents stated that they close to "strongly agree." It can be found that the weighted average yield for all aspects is 4.5 . While the results of the assessment of the performance of headmaster's managerial performance filed online can be seen in Table 2 below

Table 2. Result of Online Assessment on The Formal of Principal Managerial Performance Management Instrument

\begin{tabular}{|c|c|c|c|c|c|c|c|c|}
\hline \multirow{2}{*}{$S_{0}$} & \multirow{2}{*}{ Aupek yang dinlai } & \multicolumn{5}{|c|}{ Toal Ansus: } & \multirow{2}{*}{$\begin{array}{l}\text { Wewhes } \\
\text { Score }\end{array}$} & \multirow{2}{*}{$\begin{array}{l}\text { weived } \\
\text { Iane }\end{array}$} \\
\hline & & 34 & 4 & $\angle A$ & D & SD & & \\
\hline$t$ & Quin Doply trig harars & $n$ & 7 & & 1. & & 14 & 47 \\
\hline 2 & Nerachary & 5 & in & 2 & 3 & & 111 & 18 \\
\hline 3 & Oparixai Ese & $n$ & 8 & & 2 & & 135 & 45 \\
\hline 4 & Ceeforsiny Chove deign & is & 30 & 3 & 2 & & 123 & 43 \\
\hline 5 & Accercy of nod mage & 3 & $n$ & 2 & 3 & & 111 & 19 \\
\hline \multirow[t]{4}{*}{1} & Actancy of lanpare wast & 7 & $y$ & 4 & 2 & & 18 & 10 \\
\hline & Tient & & & & & & & $24 \mathrm{I}$ \\
\hline & Wastad Mtes & & & & & & & 41 \\
\hline & 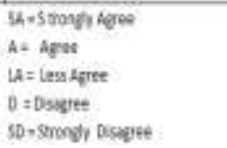 & & & & & & & \\
\hline
\end{tabular}

Table 2, presents the results of assessments by the headmasters regarding the format of the instrument and the results of the calculations can be explained as follows:

The number of headmasters who did assessment was thirty people; they are the headmasters of elementary schools with the national standard.

In the instrument, there are six aspects which are assessed; its scale is 1 to 5 . They are: "strongly agree" 
(weight 5); "agree" (weight 4); "disagree" (weight 3); "disagree" (weight 2); and "strongly disagree" (weight 1).

The scoring used weighting and weighted average. In the 1 st aspect of "quality display design Instrument" most answered "very agree" that as many as 22 people and seven people "agreed", and one "does not agree" then the weighted score is $=(22 \times 5)+(7 \times 4)+(0 \times 3)+(1 \times 2)+$ $(0 \times 1)=140$ so for weighted average obtained $=140: 30$ $=4.7$. In the same way for aspect No. 2 and so on until No. 6, the result of Weighted Average is =."Clarty menu aspect $"=4.8$, "Operational Ease" = 4.5, "Conformity Choose design" $=4.3$. "Accuracy of word usage" $=3.9$ "Accuracy of language usage" $=3.6$. Thus it can be seen that some respondents stated: "strongly agree" with the statement of operational "Ease" and "Conformity Choose design" and some "agreed" with the "Accuracy of language usage " statement, it seems very clear and it related to the menu format. Besides, some respondents stated that it is very easy to operate, whereas the suitability of the selection of instrument type assessment mostly stated very appropriate. Words and Languages used are also correct. Based on the calculation of all aspects it can be found that the weighted average yield for all aspects is 4.1. It can be analyzed that the respondents agree with the statement in the instrument.

The outcomes of this experiment about the content of all aspects of Headmaster's Managerial Performance through online instrument show that the headmasters stated that all aspects of the instrument meet the qualification and correspond to the Headmaster's Managerial Competence. It can be found in Table 1 and Table 2 shows that the average score is 4.5 and 4.1 respectively. It can be analyzed that the instrument is eligible to be applied. Based on the data obtained, there are also some reasons, comments, and suggestions from the respondents. There are also some reasons, comments, and advice from the Headmaster of Elementary School. All of them say that all the Managerial Performance Assessment Instruments of the headmasters are appropriate and referred to the standard of competence or if they are not perfect, and preferably before the innovation of the model, there should be a socialization to the headmaster and school supervisor.

In this experiment, the School Supervisor also conducted an assessment of the Headmaster Managerial Performance Instrument, in the form of an online checklist, and agreed, and the result of the calculation of a weighted average score of 4 . However the supervisor also conducted a pilot assessment of a). Headmaster's Identity data form, b) the instrument of briefly filling content, c) a checklist, d) an observation and interview guide, the performance assessment test form, the conclusion and recommendation form, and portfolio.

The results of the evaluation by the School Supervisor on the Headmaster Managerial are in Table 3 below.
Table 3. The results of the assessment by the School Supervisor on the Headmaster Managerial Assessment Performance Instrument and the results of its calculations

\begin{tabular}{|c|c|c|c|c|c|c|c|c|}
\hline \multirow[b]{2}{*}{ No } & \multirow[b]{2}{*}{ fustrumats } & \multicolumn{5}{|c|}{ Total Aouner } & \multirow{2}{*}{$\begin{array}{l}\text { Weighted } \\
\text { Soore }\end{array}$} & \multirow{2}{*}{$\begin{array}{l}\text { Weghtes } \\
\text { Moan }\end{array}$} \\
\hline & & sa & A & $\angle A$ & 0 & 30 & & \\
\hline 1 & The headioster' i identry data fornt & 5 & 5 & 0 & 0 & 0 & 45 & 4.5 \\
\hline 2 & The intrumet of brits slite conteat & 3. & 4 & 0 & 3 & 0 & 37. & 3.7 \\
\hline 3 & A bock hit & 2 & 8 & 0 & D & 0 & 42 & 4.1 \\
\hline 4 & As observatise and intervies gride & 4 & 6 & 0 & 0 & 0 & 44 & 44 \\
\hline 3. & The questionar coline. & 1 & 9 & 0 & 2 & 0 & 39 & 3.9 \\
\hline 6. & $\begin{array}{l}\text { The acheveneat wote dring the peocess of } \\
\text { assessuet }\end{array}$ & 1 & 9 & 0 & 0 & 0 & is & 4.5 \\
\hline 7 & The peffornuce assesanrt lest fim & 2 & a & 0 & 0 & 0 & 42 & 4.2 \\
\hline 8 & The coochrisa and secocunendricn foum & 4 & 6 & 0 & 0 & 0 & u & 44 \\
\hline 9 & Pondobs & 1 & 5 & 0 & 2 & 0 & 19 & 3,9 \\
\hline & Total & & & & & & & 39.7 \\
\hline & Auerze of Wethodrod Stein & & & & & & & 3.1 \\
\hline & 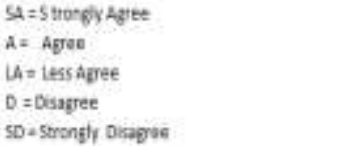 & & & & & & & \\
\hline
\end{tabular}

Table 3

The results of the assessment by the School Supervisor on the Headmaster Managerial Assessment Performance Instrument and the results of its calculations

Table 3. above presents the results of the assessment by the School Supervisor on the Headmaster Managerial Assessment Performance Instrument and the results of the calculation are as follows:

The number of elementary school supervisors who assessed it as many as ten people. In the Instrument, there are nine aspects of the assessment. The details are as follow: a scale of 1 to 5 they're "strongly agree" (weight 5), "agree" (weight 4), "disagree" (weight 3), "disagree" (weight 2) and "strongly disagree" (weight 1). The Scoring uses Weighting and weighted average. In the 1st aspect of "The headmaster's identity data form" which answered "very agree" as many as 5 people and the answer "agreed" as many as 5 people, then the weighted score is $=(5 \times 5)+(5 \times 4)+(0 \times 3)+(0 \times 2)+$ $(0 \times 1)=45$, for weighted average obtained $=45: 10=$ 4.5. By the same calculation method for aspect no 2 and so on until 9, the weighted average result for the "The instrument of briefly filling content" the answers are varied, with weighted average $=3.7$. For " A checklist "most school supervisors agreed with a weighted average score of 4.2. Meanwhile" an observation and interview guide," $2 / 3$ of the respondents (the supervisor) stated strongly agree with the weighted average of 4.4 . For the online questioner partially agreed, with the weighted average score $=3.9$. Seeing the achievement note during the process of assessment "some respondents, strongly agree, and some agree, with a weighted value of 4.5. Most of them $(80 \%$ of supervisors agreed with, "The Performance Assessment test form" and the average 
value $=4.2$, for "The conclusion and recommendation form", with a weighted mean value of 4.4 , and shown by 2 / 3 respondents agreed with the statement, while for "Portfolio" with a weighted value of 3.9 and indicated by, $3 / 10$ strongly agree $1 / 2$ of the number of supervisors agreed, $1 / 5$ of the number of respondents disagreed. Based on the calculation of all aspects, it is clear that most of the respondents agree with the above statement it can be seen that the weighted average result for all aspects is 3.8. Thus it can be analyzed that the instrument is eligible to be applied.

\section{Suggestion given}

Based on the supervisor's opinion: that the Headmaster's identity data is very complete and the observation sheet is appropriate. However, because it is done during the process and it is done step by step, so it is necessary to have an incident or anecdotal record. It is also a need that the interview guide is made more structured as input so that the headmaster's achievement record is added to the photocopy of documents or authentic evidence. Data on performance assessment instruments conducted online will be more useful if the points of the statements shown more accurate. The conclusion and recommendation formats are appropriate. So far the assessment of the Headmaster's Performance is more on administrative assessment, such as financial administration, infrastructure, KBM files so that the data obtained complete and eventually become a full portfolio. evaluation provide a statement about the model of the principal managerial performance assessments tested can be seen in table 4 below

Table 4.The respon of the expert about the Assessment Performance Instrument and the results of its calculations

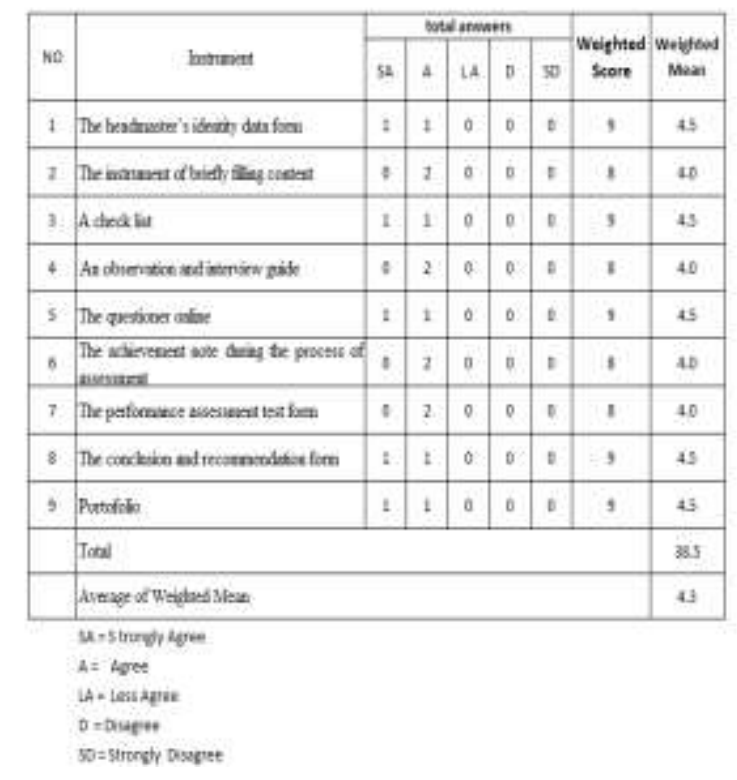

Table 4. presents the Expert's assessment results on the Headmaster Managerial Assessment Performance Instrument and the results of the calculations can be explained as follows :

Number of Experts who assessed as many as 2 people, they come from Jakarta State University. in Instrument, aspects that are assessed there are 9 aspects, have a scale answer 1 to 5 that is, "strongly agree (weight 5), agree (4), less agree (3), Disagree (2) and strongly disagree (1).

Scoring using Weighting and weighted average. In the 1 st aspect of "The headmaster's identity data form" which answered very agree as many as 5 people and the answer agreed 5 people, then the weighted score is = $(1 \times 5)+(1 \times 4)+(0 \times 3)+(0 \times 2)+(0 \times 1)=9$, for weighted average obtained $=9: 2=4.5$. In the same way for aspect No. 2 and so on until No. 9, the weighted average results for "The instrument of briefly filling content" $=4.0$ are both agreed

"A check list" with average $=4.0$, which means agree "An observation and interview guide and" The questioner online "weighted average is $=4.5$ which means approached strongly agree," The achievement note during the process of assessment $"=4.0$, "The performance assessment test form" $=4.0$, "The conclusion and recommendation form", = 4, which means agree. For "Portfolio" is known with the average value $=4.5$. The assessment is known from the opinion of 2 experts who stated strongly agree while an expert agreed

The input and suggestions for the direction of the improvement of the instrument model

Based on the opinion of experts, ie from universities and from educational institutions on the model of managerial performance assessment shows that all managerial aspects are contained in the principal managerial performance assessment instrument, with various types of assessment so that it can be stated the development and qualify for material Consideration to be applied in the principal managerial performance assessment. The advice proposed by experts is

1) the need for ease understand and complete scoring techniques.

2).the need for guidance assessment on each instrument type with more clear and complete.

3).the need for socialization of model innovation for a whole elementary school in DKI Jakarta area.

\section{CONCLUSIONS}

Based on the data collected and analyzed it can be concluded as follows :

The current Principal Managerial Performance Management Instrument Model (still in use) has not yet been used online and is still manual

The Development of Headmaster Managerial Performance Assessment Model instrument needs to be done so that the assessment of the principal really measures all measured aspects and the process of processing results is fast, thus it is necessary to improve the model of principal managerial performance 
assessment. The improvements made by researchers is part of the instrument is done online. In this case the intended instrument does not reduce the contents of previous instrument.

(1) Instrument contains all aspects of principal managerial performance (2). Every sentence on the instrument can be read easily and understandably. (3). The filling is easy and takes a short time. (4). There is innovative value in charging compared to previous Instrument with the online system, previously it is not online (5). The filling instructions are easy to understand. (6). Save paper because it directly uses computer or HP based on android (7) it is easy for data collection, simply by pressing the SUBMIT button. The opinions of principals, supervisors, reviewers suggest which atated that the developed instrument is appropriate to be used and satisfy the aspects assessed in the principal's managerial competence. The instrument model which is developed is a). The headmaster's identity data form.b) The instrument of briefly filling content, c) .A check list, d).An observation and interview guide, e) .The online questioner

(Akses: bit.ly/KuesionerKepalaSekolah),f).The achievement note during the process of assessment, g). The performance assessment test form that should be filled with, and $h$ ). The conclusion and recommendation form that should be filled with. in this study the some formulation of an effective headmaster's managerial performance assessment model for elementary schools are the appropriate rating-model used is rating scale, checklist, behaviorally Anchored Rating Scale and management approach by objective.

3.Based on the results of the opinion test from the principal, supervisors and experts on the development of the assessment model stated that most of them strongly agree with the instruments being tested. The performance Assessment model has fulfilled the Principal Managerial aspect and does not deviate from the established competency standard.

4.Models are tailored to the needs of schools and technological developments as well as supporting the improvement of the quality of education, thereby effectively being an innovative model that is eligible and eligible to apply.

\section{REFERENCES}

[1] Imron,Peranan Kepala Sekolah Menengah Pertama dalam Manajemen Berbasis Sekolah.(Jurnal Manajemen Pendidikan.Volume 23,2011).

[2] Hoy dan Miskel, Educational Administration.Theory ,Research and Practices.New York:Mc Graw Hill
International Editional.2005.

[3] Sudji,Pengembangan Model Penyiapan Guru dan Penjaminan Mutu guruPasca sertifikasi (UNY.Yogyakarta,2008)

[4] W.J.S Poerwodarminto in the Indonesian general dictionary

[5] Michael Armstrong, Performance Management: Key Strategies and Practical Guidelines-3rd ed (London: United Kingdom, 2006)

[6] Richard L. Hughes, Robert C. Ginnett, dan Gordon J. Curphy, Leadership: Enhancing the Lessons of Experience (New York: McGraw-Hill, 2009).

[7] Sabine Sonnentag, Psychology Management of Individual Performance A Handbook in the Psychology of Management in Organizations (New York: John Wiley and Sons. Ltd, 2002)

[8] Burhanudin,Analisis Administrasi Manajemen dan Kepemimpinan Pendidikan,(Jakarta :Bumi Aksara 2000).

[9] Dirawat Busro Lamberi dan Sukarto Indrafachrudi ,PengantarKepemimpinan pendidikan,(Surabaya:Usaha Nasional.1993 )

[10] Mulia Nasution ,Manajemen Personalia( Jakarta : Jambatan,2000).

[11]Hari Setiadi, PenilaianKinerja (Jakarta Puspendik Balitbangnas(Depdikas,2006).

[12] Wahyu Sumijo ,Kepemimpinan Kepala Sekolah ,Tinjauan teoritik dan Permasalahannya ,(Jakarta: PT .Raja Grafindo Persada. 2008 ).

[13]Sjafri Mangkuprawira Manajemen Sumber Daya Manusia (Jakarta: Galia Indonesia,2003 ) .

[14] Sjafri Mangkuprawira Sumber Daya Manusia (Jakarta: Galia Indonesia,2003 )

[15] Udin Sayefudin Saud danAhmadi Pengembangan kinerja kepala sekolah dasar(studi tentang pengaruh diklat dan kompetensi terhadap kinerja kepala sekolah SD di kabupaten Natuna Provinsi kepulauan Riau).

[16] Teguh Triwiyanto (2014)Pelaksanaan Monev dan pelaporan untuk penilaian kinerja Kepala Sekolah,p.

[17]Dedeh Saadah (2013) Kinerja Kepala Sekolah Dasar,Studi Korelasi antara iklim.

[18]Peraturan Menteri Pendidikan Nasional Republik Indonesia nomor 13 tahun 2007 tentang Standar Kepala Sekolah/Madrasah.

[19]Peraturan Pemerintah Nomor 19 Tahun 2005 tentang Standar Nasional Pendidikan.

[20] Permendiknas Nomor 19 Tahun 2007 tentang Standar Pengelolaan Pendidikan.

[21]Peraturan Menteri Pendidikan Nasional Nomor 28 Tahun 2010 tentang Penugasan Guru sebagai Kepala Sekolah/Madrasah. 